Kumawula, Vol. 2, No.1, April 2019, Hal 49 - 58 DOI:http://10.24198/kumawula.v1i3.23896

ISSN 2620-844X (online)

Tersedia online di http://jurnal.unpad.ac.id/kumawula/index

\title{
SOSIALISASI INDUSTRI DAN PERDAGANGAN DI KECAMATAN ANDIR KOTA BANDUNG
}

\author{
Ria Arifianti ${ }^{1}$, Moh. Benny Alexandri ${ }^{2}$, Lina Auliana ${ }^{3}$ \\ Departemen Administrasi Bisnis Universitas Padjadjaran \\ 1*r.arifianti@unpad.ac.id
}

\begin{abstract}
ABSTRAK
Kecamatan Andir merupakan kecamatan di kota Bandung yang mempunyai industri berjumlah 137 unit. Kecamatan Andir memiliki 3 pasar, 60 pertokoan, 51 mini market dan 1 departement store.

Data tersebut merupakan data kongkrit dan tidak terpantau perkembangannya. Oleh karena itu diperlukan sosialisasi kepada masyarakat dengan melakukan pengabdian pada masyarakat. Pengabdian ini dengan mengadakan sosialisasi tentang industri yang ada.

Metode pengabdian pada masyarakat adalah metode ceramah, metode tanya jawab dan metode diskusi.

Hasil yang didapat mengungkapkan bahwa Kecamatan Andir mempunyai potensi yang tinggi dalam perkembangan industri di Bandung, tetapi terdapat masalah permodalan dalam pengembangan industrinya. Saran diberikan Kecamatan Andir melalukan sosialisasi tentang adanya produk-produk perbankan yang memberikan kredit UMKM. Kecamatan Andir melalui Kelurahan menjembatani kerjasama atau kemitraan antara pedagang dengan instansi perbankan terkait
\end{abstract}

Kata Kunci : Industri, Kecamatan, Andir, Bandung

\section{SOCIALIZING REGARDING INDUSTRY AND TRADE IN ANDIR SUB- DISTRICT, BANDUNG CITY}

\begin{abstract}
Andir Sub-district is a sub-district located in Bandung City that has 137 units of industry. Andir Sub-district has 3 markets, 60 stores, 51 mini-markets, and 1 departement store.

The data is concrete and it's development has not been monitored. Therefore socialization is needed for the public in through social services. The social services rely on socialization of the industries that are already in Andir Sub-district.

The method of social service to the public are, through talks, questions and answers sessions, and also discussions.

The results show that Andir Sub-district has high potential with regards to developing it's industry in Bandung, but they are faced with modeling the development of their industry. It is advised that the Andir government socialize to it's public regarding banks that give out UMKM credits. Andir Sub-district through the Village Office should be the bridge that facilitates cooperation and partnership between industry owners and relevant banking agencies.
\end{abstract}

Keywords: Industry, Sub-district, Andir, Bandung 


\section{PENDAHULUAN}

Industri memiliki kontribusi terhadap pertumbuhan ekonomi suatu wilayah sehingga industri selalu diusahakan agar terus meningkat dan merata di setiap wilayahnya. Menurut Badan Pusat Statistik (BPS) Kota Bandung, pendapatan Kota Bandung meningkat sebanyak 4,18 persewn dari tahun 2016 sampai 2017 dengan penyumbang terbesar yakni Pendapatan Asli Daerah (PAD) dan Dana Perimbangan. Melihat dari Pendapatan Asli Daerah (terdapat industri yang menjadi penyumbang sebanyak $0.3 \%$ dari pendapatan daerah Kota Bandung. BPS mengklasifikasikan industri menjadi industri besar, menengah dan kecil. Jumlah industri besar di Kota Bandung sebanyak 253 unit, industri sedang 835 unit dan industri kecil 9760 unit. (Pujiawati, 2018)

Kecamatan Andir merupakan kecamatan yang berada di sebelah Barat Kota Bandung.Kecamatan ini terdiri dari Kelurahan Campaka, Kelurahan Maleber, Kelurahan Garuda, Kelurahan Dungus Cariang, Kelurahan Ciroyom dan Kelurahan Kebon Jeruk. Sebanyak 3,94 persen penduduk Kota Bandung bertempat tinggal di Kecamatan Andir. Jumlah seluruh industri di Kecamatan Andir sebanyak 137 unit. Kecamatan Andir memiliki 3 pasar, 60 pertokoan, 51 mini market dan 1 departement store, 61 gerai (survei lapangan, 2019)

Banyaknya industri yang terdapat di Kecamatan Andir menunjukkan tingginya kontribusi industri di Kecamatan Andir dalam PAD Kota Bandung. Didukung dengan terdapatnya industri besar yaitu pasar dan departement store, selain itu juga industri menengah dan kecil dalam jumlah yang cukup banyak turut berkontribusi. Dengan data-data tersebut, akan dilakukan pemetaan terhadap industri dan perdagangan yang terdapat di Kecamatan Andir karena kontribusinya dalam Pendapatan Asli Daerah Kota Bandung. Selanjutnya hasil kegiatan pemetaan tentang industri tersebut, dilakukan Sosialisasi Industri dan Perdagangan di Kecamatan Andir Kota Bandung

\section{Identifikasi Masalah}

Adapun untuk pelatihan Aktivasi Bisnis indikator dan pencapaian yang ingin dicapai adalah:

\begin{tabular}{|l|l|ll|}
\hline No & \multicolumn{1}{|c|}{ Indikator } & \multicolumn{2}{|c|}{ Pencapaian setelah kegiatan } \\
\hline 1. & $\begin{array}{l}\text { Data tentang jumlah industri dan perdagangan Di } \\
\text { Kecamatan Andir Kota Bandung }\end{array}$ & $\begin{array}{l}\text { Peserta mengetahui dan merevisi } \\
\text { dengan data terbaru }\end{array}$ \\
\hline 2. & Mendata hambatan yang terjadi & $\begin{array}{l}\text { Peserta mengetahui dan mencari } \\
\text { solusi pemecahannya }\end{array}$ \\
\hline
\end{tabular}

Berdasarkan hal tersebut, maka perlu diadakan sosialisasi industri dan perdagangan di Kecamatan Andir Kota Bandung. 


\section{A. Tujuan}

1. Menyampaikan perkembangan industri dan perdagangan di Bandung khususnya Kecamatan Andir Kota Bandung

2. Memberikan sosialisasi industri dan perdagangan di Bandung khususnya Kecamatan Andir Kota Bandung

\section{B. Hasil yang diharapkan}

Para peserta dapat mengetahui, memahami, dan memecahkan masalah yang ada dalam industri dan perdagangan di Kecamatan Andir Kota Bandung.

\section{KAJIAN PUSTAKA}

\section{Kawasan Industri}

Kawasan Industri adalah kawasan tempat pemusatan kegiatan industri yang dilengkapi dengan sarana dan prasarana penunjang yang dikembangkan dan dikelola oleh Perusahaan. (Anif Rizqianti Hariz, Purwanto, Suherman. 2018 : 58, Undang-undang Republik Indonesia Nomor 3, Tahun 2014)

Kegiatan untuk mendorong adanya pertumbuhan dalam sektor industri yang terarah, terintegrasi dan memberikan manfaat yang lebih optimal bagi suatu daerah serta kawasan industri berlokasi merupakan suatu tujuan pengembangan Kawasan industri. Efisiensi, tata ruang dan lingkungan hidup merupakan dasar dari konsep pengembangan industri.

Landasan pokok dalam pengembangan Kawasan industri adalah efisiensi, Esiensi dalam hal ini berkaitan dengan keuntungan dan kemanfaatan dari industri. Keuntungan dari segi investor adalah para pengguna kapling industi akan mendapatkan lokasi industri yang diinginkan sudah tertata dengan baik, dengan adanya keuntungan yang di dapat seperti adanya bantuan dalam proses perijinan, Infrastruktur yang tersedia dan yang lengkap, Adanya keamanan dalam menjalankan usaha dan adanya kepastian dari segi tempat usaha dan sesuai dengan Rencana Tata Ruang Daerah. Sedangkan keuntungan dari sudut pemerintah daerah adalah efisiennya jaringan infrastruktur yang disediakan ke kawasan industri dalam perencanaan infrastruktur dan kapasitas yang ada telah sejalan dengan kegiatan industri yang berada di kawasan industri.

Dari aspek tata ruang, dengan adanya kawasan industri maka masalah-masalah konflik penggunaan lahan akan dapat dihindari. Demikian pula, bilamana kegiatan industri telah dapat diarahkan pada lokasi peruntukannya, maka akan lebih mudah bagi penataan ruang daerah, khususnya pada daerah sekitar lokasi kawasan industri. 
Dari aspek lingkungan hidup, konsep pengembangan kawasan industri jelas mendukung peningkatan kualitas lingkungan daerah secara menyeluruh. Dengan dikelompokkan kegiatan industri pada satu lokasi pengelolaan maka akan lebih mudah menyediakan fasilitas pengolahan limbah dan juga pengendalian limbahnya. Sudah menjadi kenyataan bahwa pertumbuhan industri secara individual memberikan pengaruh besar terhadap kelestarian lingkungan karena tidak mudah untuk melakukan pengendalian pencemaran yang dilakukan oleh industri-industri yang tumbuh secara individu.

1. Besaran permintaan lahan (land demand)

2. Kecenderungan jenis industri yang tumbuh

3. Berbagai permasalahan lingkungan yang sudah dan mungkin timbul sebagai akibat dari pertumbuhan industri yang ada.

4. Ketersediaan prasarana

5. Ketersediaan Sumber Daya Manusia (SDM)

(Sumber : Departemen Perindustrian dan Perdagangan, 2013).

\section{Metode Pelaksanaan PKM}

Kegiatan sosialisasi digunakan beberapa metode, antara lain :

1. Metode ceramah, yaitu digunakan pemateri untuk memaparkan hasil pemetaan yang telah dilakukan.

2. Metode Tanya Jawab, yaitu digunakan untuk menanggapi tingkat pemahaman atau pengetahuan peserta sosialisasi terhadap pemaparan hasil pemetaan tersebut. Peserta sosialisasi adalah Camat, para Lurah dan Tim.

3. Metode diskusi, yaitu pemateri dan para peserta melakukan pembahasan tentang kondisi industri yang ada dan mencari solusi tentang masalah yang timbul.

\section{HASIL DAN PEMBAHASAN}

\section{Pengumpulan Data}

\section{Kelembagaan Kelurahan}

Kecamatan Andir dibagi dalam 6 Kelurahan dalam melaksanakan kegiatan operasional pemerintahan. Data tentang unsur pemerintahan (dalam hal ini Rukun Tetangga dan Rukun Warga) di 6 kelurahan adalah sebagai berikut : jumlah RT dan RW adalah berjumlah 381 RT dan 54 RW. (Pujiawati, 2018) Rinciannya komposisinua sebagai berikut :

1. Kelurahan Kebon Jeruk terdiri atas 72 RT, 9 RW, 
2. Kelurahan Ciroyom terdiri atas $87 \mathrm{RT}$, dan $10 \mathrm{RW}$

3. Kelurahan Dunguscariang terdiri atas $84 \mathrm{RT}$, dan $11 \mathrm{RW}$

4. Kelurahan Garuda terdiri atas $38 \mathrm{RT}$ dan $6 \mathrm{RW}$

5. Kelurahan Maleber terdiri atas $62 \mathrm{RT}$ dan $11 \mathrm{RW}$

6. Kelurahan Campaka terdiri atas 38 RT dan 7 RW

Berdasarkan wawancara yang dilaksanakan dengan Pak Agus, salah satu ketua RW di Kelurahan Garuda, masyarakat cenderung berperilaku pasif terhadap program-program pemerintah dalam bidang ekonomi. Berdasarkan hasil wawancara, sebagian besar dari pelaku bisnis masih belum mempunyai strategi dalam mengembangkan bisnisnya, padahal strategi sangat penting untuk mengembangkan bisnis. Beberapa aspek seperti pembentukan tim, relasi, pengelolaan keuangan, pemasaran, dan lain-lain masih belum dilaksanakan dengan maksimal.

Berdasarkan data yang diperoleh dari kajian lapangan, jumlah pelaku industri masih tertutup dan perkembangan usahanya masih rendah dan bisnis yang sudah berjalan dengan baik karena terbentur masalah modal. Data tersebut melatarbelakangi pelaksanaan kegiatan sosialisasi di Kecamatan Andir yang sasarannya adalah masyarakat dari masing-masing kelurahan. Kegiatan tersebut bertujuan untuk meningkatkan minat, kemampuan, serta pemahaman masyarakat terhadap seluk-beluk UMKM yang kemudian diharapkan akan memajukan usaha tingkat menengah dan usaha tingkat kecil yang ada di Kecamatan.

Kecamatan Andir mempunyai daerah perdagangan yang berkaitan dengan industri baik pasar tradisional maupun industri kreatif. Kecamatan Andir didominasi oleh pasar tradisonal maupun pasar modern. Pasar tradisional yang popular di Wilayah Kecamatan Andir ini terdapat Pasar Ciroyom yang masuk ke dalam wilayah Kelurahan Ciroyom dan sebagian yang dekat rel kereta api masuk ke dalam wilayah Kelurahan Dungus Cariang, Pasar Ciroyom dan Pasar Andir ini merupakan pasar tradisional berskala besar di kota Bandung, di dalam pasar tersebut penjualnya mayoritas menjual sayur-sayuran, buah-buahan, ikan, daging dari mulai daging ayam, daging kambing dan daging sapi, bahkan di pasar ini pun dapat ditemukan daging babi untuk dikonsumsi, dan di pasar tradisional ini juga dijual berbagai macam kebutuhan pokok lainnya.

Selain pasar Ciroyom, terdapat pasar Andir yang terkenal sentra industrinya. Sentra industri yang dimaksud adalah berupa industri tekstil berupa kain dan pakaian. Pakaian di pasar Andir ini, diminati oleh para pedagang yang berbasis online.

Selanjutnya adanya pasar modern yang merupakan pusat tekstil lainnya yaitu Pasar Baru. Konsep Pasar Baru memadukan pasar modern dan pasar tradisional. Di dalam kawasan 
Pasar Baru terdapat sejumlah penjual yang bergerak di bidang tekstil mulai dari penjual kain, sampai dengan penjual baju-baju yang sudah siap untuk dipakai.

Perdagangan yang ada dalam wilayah Kecamatan Andir ini menjadi pusat perhatian karena titik-titik perekonomian besar berada di wilayah ini. Terdapat banyak industri yang ada di Kecamatan Andir ini mulai dari industri mikro, industri kecil, industri menengah sampai industri besar.

Mayoritas dari masyarakatnya terjun langsung ke dalam industri perekonomian mulai menjadi produsen, supplier, menjadi, agen, sebagai penjual di pasar, bahkan yang tingkat rumah tangga pun terdapat banyak industri rumahan yang menjamur

Tingkat keinginan dari tiap masyarakatnya untuk memajukan kesejahteraanya dengan bergelut di bidang ekonomi ini sangat penting karena mulai dari rasa ingin melakukan usaha inilah yang akan membawa ke kesejahteraan yang diharapkan.

Oleh karena itu, hasil yang di dapat dari lapangan dipetakan dalam bentuk pemetaan yang akan disajikan dalam kegiatan sosialisasi. Pemetaan adalah merupakan suatu proses untuk menyatakan suatu tempat, dalam hal ini industry di Kecamatan Andir.

Sosialisasi merupakan suatu proses interaksi sosial yang mengakibatkan seseorang secara individu mengenal cara untuk berpikir, berperasaan, dan berperilaku sehingga membuat individu tersebut dapat berperan serta dalam kehidupan masyarakatnya (Vander, 1979: 75). Proses sosialisasi tersebut adalah adanya interaksi individu dengan lingkungannya. Proses tersebut seorang individu dapat dibentuk untuk berperilaku sesuai dengan perilaku kelompoknya dan melakukan pembelajaran menjadi warga masyarakat tempat ia menjadi anggotanya (Berger, 1984: 116). Hal ini dilakukan di dalam kegiatan sosialisasi di Kecamatan Andir. Dalam melakukan sosialisasi ini, adanya interaksi antara pelaku kegiatan pengabdian kepada masyarakat dengan pelaku industri yang berada di lingkungan kecamatan Andir. Kondisi di masing-masing Kelurahan :

\section{1) Kelurahan Garuda}

Kondisi di lokasi kelurahan garuda ini berdasarkan data yang didapatkan dan berdasarkan wawancara dengan beberapa pelaku usaha ini yakni bahwa di kelurahan Garuda ini ada beberapa daerah atau wilayah-wilayah yang menjadi pusat perdagangan. Di wilayah Kelurahan Garuda ini tidak ada pasar sebagai tempat atau pusat kegiatan ekonomi, warga yang ada di wilayah ini biasanya untuk belanja ke pasar Ciroyom yang terletak di Kelurahan Ciroyom dan apabila berbelanja ke pasar modern masyarakat kelurahan Garuda akan memilih 
ke Super Indo yang ada di kelurahan ini. Pusat perdangan dalam wilayah Kelurahan Garuda ini berada di beberapa titik yakni :
1) Di Jalan Elang Raya
2) Di Jalan LMU Nurtanio
3) Di depan SD Dadali - Garuda
4) Di depan Puskesmas Garuda
5) Di depan SD YWKA

Industri yang ada didominasi oleh pemilik usaha kecil yang memproduksi barangnya sendiri dan menjual barangnya sendiri yang umumnya mereka berjualan dengan menggunakan gerobak. misalnya penjual keripik, penjual rujak, penjual kue ape, kue cubit, mie telor goreng dan rumah makan padang. Selain adanya pertambahan penjual tertentu ada juga beberapa penjual yang mana sudah tidak berjualan produk terkait lagi misalnya penjual mie goreng, penjual gado-gado, penjual singkong atau jagung, krepes, seblak, pulsa, nugget, pisang keju, dan roti bakar.

Selanjutnya industri yang berkembang adalah Toko Kue Erlanda. Toko kue ini berdiri pada tahun 1978. Toko kue ini menjual kurang lebih 60 jenis kue yang berbeda. Pelanggannya adalah universitas-univesitas di Bandung seperti UNPAS, Maranatha dan STT Telkom. Omzet yang didapatkan dalam satu hari kurang lebih mencapai 1 juta pada tahun 2010 dan 200-300 ribu pendapatan 1 hari per roda.

\section{2) Dungus Cariang}

Di dalam wilayah Kelurahan Dungus Cariang ini terdapat cukup banyak pelaku industri, sebagaimana kita tahu bahwa di kawasan Andir terdapat Pasar Ciroyom, namun hanya sebagian dari pasar Ciroyom saja yang masuk ke dalam wilayah Kelurahan Dungus Cariang yakni bagian pasar Ciroyom yang dekat dengan rel kereta saja. Berdasarkan data yang kami dapatkan mengenai Usaha Kecil dan Perdagangan milik Kelurahan Dungus Cariang terdapat diantaranya kurang lebih 142 pelaku usaha yang terdata oleh pihak Kelurahan Dungus Cariang. Jumlah pelaku industri sebagian besar merupakan pengusaha industri besar, industri sedang dan industri kecil.,

Industri yang terkenal adalah Konveksi Kampung Tas. Konveksi ini juga menerima order selain tas dengan minimal order sejumlah 60 buah. Karyawan yang terlibat adalah 20 karyawan yang memiliki keahlian menjahit yang bekerja dari pukul delapan pagi sampai pukul lima sore. Berdasarkan wawancara dengan pelaku industri, beberapa kendala yang muncul di antaranya : 
- Waktu: waktu yang diinginkan oleh konsumen terlampau cepat sedangkan proses produksi memerlukan waktu yang cukup lama agar didapat produk yang sempurna

- Kesesuaian bahan yang diinginkan oleh konsumen dan yang didapat dari supplier apabila berbeda akan menimbulkan kerugian di masa depan misalnya konsumen yang karena bahannya tidak sesuuai mereka tidak mau mengambil barangnya dan tidak mau membayar hal ini yang mengakibatkan timbulnya kerugian.

- Gagal order: bahan sudah dibeli namun karena beberapa alasan Krisis moneter menggagalkan ordernya sehingga menimbulkan kerugian

Usaha ini memiliki strategi marketing tersendiri yakni penjualan dilakukan via online dengan membuat website yang dapat diakses oleh siapapun, selain itu agar websitenya menjadi paling atas maka harus membayar beberapa jumlah uang tertentu ke google agar google menaikkan website usaha mereka atau istilahnya pasang iklan di internet.

\section{3) Kelurahan Ciroyom}

Kelurahan Ciroyom adalah salah satu dari 6 kelurahan yang berada di dalam wilayah Kecamatan Andir, luas wilayah dari Kelurahan Ciroyom ini adalah 0,6 km2. Kelurahan ini mempunyai tempat industri sebagai berikut :

1. Pasar Ciroyom yang merupakan pasar tradisional yang di dalamnya banyak terjadi kegiatan usaha, yang di dalamnya juga terdapat banyak penjual dengan berbagai macam produk yang ditawarkan diantaranya sayur-sayuran segar, buah-buahan, dan daging dimulai dari daging sapi, ikan, daging ayam dan daging kambing.

2. Pasar Chinatown merupakan objek wisata perkampungan china sebagai bentuk dari wisata sejarah dan bentuk keberagaman.

3. Industri olahan Nugget yaitu memproduksi olahan nugget ayam dan paha ayam. Produksi yang dihasilkan setiap harinya kurang lebih sebanyak 4 karung yang mana satu karung beratnya sekitar 25 kilo. Perusahaan ini memperkerjakan Karyawan sebanyak 6 orang dalam jam kerja. Produk olahan ini Usaha ini dipasarkan di daerah Ciroyom, Baleendah, Ciparay, Cianjur. Pemasarannya dilakukan berdasarkan pesanan konsumen (make to order).

Kendala yang utama dalam industri ini dalah masalah modal.

\section{4) Kelurahan Kebon Jeruk :}

Kantor Kelurahan Kebon Jeruk berada di Jalan Babatan Nomor 2 Kecamatan Andir, Kota Bandung, Jawa Barat.

\section{5) Kelurahan Maleber :}

Kantor Kelurahan Maleber berada di Jalan Srigunting Selatan, Gg. Srigunting II Nomor 
11, Maleber. Industri yang ada di Kelurahan Maleber adalah usaha makloon yang berdiri oada tahun 1990. Permintaan makloon antara 200-500 buah dalam satu bulan. Tetapi adanya kendala dalam unsur modal. Pemasaran yang dilakukan hanya di wilayah Bandung saja. Omzet yang diterimanya kurang lebih mencapai Rp 20.000.000,-. Masalah yang ditemukan dalam industri ini adalah masalah modal.

\section{6) Kelurahan Campaka :}

Letak Kantor Kelurahan Cempaka berada di Jalan Raya Cimindi Nomor Raya, Campaka.

Industri yang ada di wilayah Kelurahan Campaka ini salah satunya adalah olahan bawang yakni bawang goreng. Usaha ini dalam satu kali produksi menghasilkan 20-30 kilogram bawang merah dan dilaksanakan dua kali dalam satu bulan. Pengemasannya secara manual, dan dijual dalam bentuk kemasan kecil sebesar lima belas ribu rupiah. Kemasan besar dibandrol sebesar lima puluh ribu rupiah.

\section{Sosialisasi}

Hasil dari pengumpulan data, maka dilakukan sosialisasi. Tujuannya adalah untuk melaporkan hasil pengumpulan dan memberikan informasi perkembangan industri yang ada di Pasar Andir. Selain daripada itu, memberikan data terbaru yang ada di Kecamatan Andir. Peserta Sosialiasi ini terdiri dari para lurah dan tim ekonomi kelurahan. Kendala yang ada adalah para pelaku industri tidak memberikan data kongkrit tentang keuntungannya, sehingga sulit untuk memetakan keuntungan yang didapat.

\section{KESIMPULAN}

\section{Kesimpulan}

Sosialisasi dilakukan mengungkapkan bahwa Kecamatan Andir mempunyai potensi yang tinggi dalam perkembangan industri di Bandung, tetapi terdapat masalah permodalan dalam pengembangan industrinya

\section{Saran}

1. Kecamatan Andir melalukan sosialisasi tentang adanya produk-produk perbankan yang memberikan kredit UMKM

2. Kecamatan Andir melalui Kelurahan menjembatani kerjasama atau kemitraan antara pedagang dengan instansi perbankan terkait 


\section{DAFTAR PUSTAKA}

Anif Rizqianti Hariz, Purwanto, Suherman. 2018. Pengembangan Kawasan Industri Ramah Lingkungan Sebagai Upaya Untuk Menjaga Keseimbangan Ekosistem (Studi Kasus di Taman Industri BSB Semarang). Al-Hayat: Journal of Biology and Applied Biology, Vol 1, No 1, Semarang.

Berger, Peter L. 1984. Invitation to Sociology: A Humanistic Perspective. USA: Penguin Books.

Pujiawati, 2018. Kecamatan Andir Dalam Angka, Bandung : Badan Pengolahan Statistik.

Undang-undang Republik Indonesia Nomor 3 Tahun 2014 tentang Perindustrian , 2003.Konsep Awal Pengembangan Kawasan Industri Berwawasan Lingkungan. -, 2013, Puslitbang Sumber Daya, Wilayah dan Lingkungan Hidup Badan Litbang

Industri dan Perdagangan Departemen Perindustrian dan Perdagangan. Jakarta.

Vander, Zanden J. W. 1979. Sociology. New York: John Wiley and Sons 